\title{
The effect of Islamic values on relational marketing basics
}

\author{
Jafar Beikzad, Ali Jahedi Chaharborj, and Saeid Ghorbannejad Maleki*
}

Department of Management, Islamic Azad University, Bonab Branch, Bonab, Iran

\begin{tabular}{l}
\hline A R T I C L E I N F O \\
\hline Article history: \\
Received October 1, 2011 \\
Received in Revised form \\
November, 14, 2011 \\
Accepted 15 December 2011 \\
Available online \\
21 December 2011 \\
\hline Keywords: \\
Islamic values \\
Relational Marketing Basics \\
Trust \\
Commitment \\
communications and Conflict \\
Management
\end{tabular}
A B S T R A C T

\begin{abstract}
In this paper, we present an empirical study to measure the relationship between Islamic values and marketing affairs in the field of alimentary industries of West Azarbaijan province, Iran. The proposed study distributes a questionnaire among 105 managers out of 145 ones and analyzes the data using different statistical methods such as linear regression analysis. The preliminary results indicate that Islamic values significantly influence trust, commitment and communication among members of business units and it could help resolve conflict management, substantially. The paper provides some guidelines for better managing firms in the region by attaching on Islamic values for marketing products and preventing unethical methods in mislead customers.
\end{abstract}

\section{Introduction}

During the past few years, there have been growing interests on executing Islamic rules for different companies such as banks, insurance companies, etc. (Hunt \& Vitell, 1986; Ahmad, 2000; Ahmad, \& Haron, 2002). Al-Khater and Naser (2003) discussed the importance of honoring ethical rules in organization to increase customers' trust and feeling towards firms. Dsuki and Abdollah (2006) investigated some important factors, which motivate customers to deal with Islamic banks specifically in a dual banking environment exists in some countries such as Malaysia. They also investigated some important factors associated with corporate social responsibility as a necessary element of potential customers' banking selection criteria. The study disclosed that the selection of Islamic banks is a combination of Islamic and financial reputation and quality service offered by the bank.

There are also other important factors including good social responsibility practices, convenience and product price. Wilson (1997) presented a comprehensive study on Islamic finance and ethical investment. Arslan (2001) discussed influencing moral issues affecting the success of business in

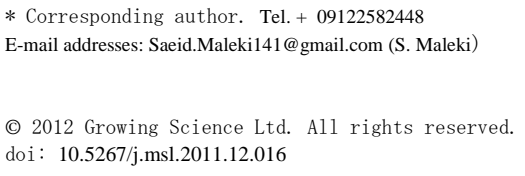


different countries. Lund (2000) performed an empirical examination of marketing professionals' ethical behavior in differing situations. Ndubisi (2007) performed a comprehensive study on relationship marketing and customer loyalty.

Morgan and Hunt (1994) presented a comprehensive study on the relationship between the components of commitment and trust using theory of relationship marketing. Othman and Owen (2001) proposed a method for adopting and measuring customer service quality in Islamic banks. They investigated their studies for a case study in Kuwait finance house and analyzed their results. Porter and Kramer (2002) presented a detailed discussion on the competitive advantage of corporate philanthropy.

The organization of this paper investigates the impact of Islamic rules and regulation on other factors such as trust, loyalty, etc. The organization of this paper first presents details of the survey and sampling as well as definitions of hypotheses in section 2. Section 3 presents details of finding and finally concluding remarks are given in the last to summarize the contribution of the paper.

\section{Research methodology}

The empirical study of this paper has been implemented among the managers of 145 people of West Azarbaijan alimentary. In order to select statistical sample from community, classified random sampling has been used. Therefore, we could use the following formula to calculate the minimum number of sample size,

$$
n=\frac{N \times z_{\alpha / 2}^{2} \times p \times q}{\varepsilon^{2} \times(N-1)+z_{\alpha / 2}^{2} \times p \times q},
$$

where $N$ is the population size, $p=1-q$ represents the yes/no categories, $z_{\alpha / 2}$ is CDF of normal distribution and finally $\varepsilon$ is the error term. Since we have $p=0.5, z_{\alpha / 2}=1.96$ and $N=145$, the number of sample size is calculated as $n=105$. In our sampling, first community has been divided into 14 towns and after calculating the shares of every town in sample, the determined number of statuses were selected from every class, through random simple sampling, which are shown on Table 1.

\section{Table 1}

Number of statistical community and sample by town division

\begin{tabular}{clcc}
\hline Rank & Town Name & Number of Community & Number of Sample \\
\hline 1 & Orumieh & 55 & 40 \\
2 & Oshnavieh & 3 & 2 \\
3 & Bukan & 5 & 4 \\
4 & Piranshahr & 4 & 3 \\
5 & Poldasht & 1 & 1 \\
6 & Chalderan & 1 & 1 \\
7 & Khoy & 17 & 12 \\
8 & Sardasht & 8 & 6 \\
9 & Salmas & 13 & 9 \\
10 & Shahindezh & 3 & 2 \\
11 & Makoo & 5 & 4 \\
12 & Mahabad & 14 & 8 \\
13 & Miandoab & 11 & 10 \\
14 & Naghadeh & 5 & 3 \\
\hline & & Sum & 145 \\
\hline
\end{tabular}


For data gathering, there were two segment questionnaires. First segment includes relational marketing basics questions with 47 questions and second segment includes 13 questions of Islamic values have been arranged and have been used. Table 2 shows details of our questions and their titles.

Table 2

Relational marketing dimensions and number of related questions of every element in questionnaire

\begin{tabular}{|c|c|c|c|}
\hline $\begin{array}{l}\text { Dimensions of relational } \\
\text { marketing basics }\end{array}$ & Elements & $\begin{array}{l}\text { Number of } \\
\text { questions }\end{array}$ & Sum of questions \\
\hline \multirow{4}{*}{ Trust } & Confidence & 3 & \multirow{4}{*}{12} \\
\hline & Treat & 3 & \\
\hline & Products Sale & 4 & \\
\hline & Presence on Number \& Mass & 2 & \\
\hline \multirow{4}{*}{ Commitment } & Services Presence & 3 & \multirow{4}{*}{13} \\
\hline & Commitment to Duties & 3 & \\
\hline & Meet Standards & 3 & \\
\hline & Quality Improvement & 4 & \\
\hline \multirow{3}{*}{ Relationships } & Presence of Information & 4 & \multirow{3}{*}{10} \\
\hline & Informing & 3 & \\
\hline & Interfaces selection & 3 & \\
\hline \multirow{4}{*}{ Conflict management } & Responsivness & 3 & \multirow{4}{*}{12} \\
\hline & Conflict Prevention & 3 & \\
\hline & Ideas submition & 3 & \\
\hline & False correction & 3 & \\
\hline
\end{tabular}
Sum of relational marketing basics questions 47

Cronbach Alpha (1951) method has been used for perpetuity calculation with SPSS software and it was 0.936 for relational marketing basics questions and was 0.921 for Islamic values questions. Value of this statistic states that first, questionnaire has high coherency second that it has high perpetuity. Cronbach Alpha was calculated as 0.936 for perpetuity of relational marketing basics questions. Cronbach Alpha is also calculated as 0.921 for Perpetuity of Islamic values questions.

\subsection{Research Hypothesis}

1. Islamic values are effective on the basics of relational marketing, which includes the following.

1.1. Islamic values are effective on trust dimension of basics of relational marketing.

1.2. Islamic values are effective on commitment dimension of basics of relational marketing.

1.3. Islamic values are effective on communications dimension of basics of relational marketing.

1.4. Islamic values are effective on conflict management dimension of basics of relational marketing.

\section{Results}

In order to analyze the collected data from questionnaires, we have used descriptive and deductive statistical methods. Table 3 shows detailed characteristics of the survey participants in terms of their gender. 
Table 3

Gender specifications

\begin{tabular}{|c|c|c|c|c|c|c|}
\hline \multirow{3}{*}{$\begin{array}{l}\text { Gender } \\
\text { answers }\end{array}$} & \multicolumn{2}{|c|}{ men } & \multicolumn{2}{|c|}{ women } & \multicolumn{2}{|c|}{ sum } \\
\hline & $\mathrm{S}$ & $\%$ & $\mathrm{~S}$ & $\%$ & $S$ & $\%$ \\
\hline & 95 & 90.5 & 10 & 9.5 & 105 & 100 \\
\hline \multirow{3}{*}{ Marital status } & \multicolumn{2}{|c|}{ single } & \multicolumn{2}{|c|}{ married } & \multicolumn{2}{|c|}{ sum } \\
\hline & $\mathrm{S}$ & $\%$ & $S$ & $\%$ & $S$ & $\%$ \\
\hline & 15 & 14.3 & 90 & 85.7 & 105 & 100 \\
\hline
\end{tabular}

Table 4

Superabundance distribution and percentage of answered questions in terms of education, years of employment and age

\begin{tabular}{|c|c|c|c|c|c|c|c|c|c|c|c|c|}
\hline \multirow{2}{*}{ Educations } & \multicolumn{2}{|c|}{ High school } & \multicolumn{2}{|c|}{ Diploma } & \multicolumn{2}{|c|}{ After diploma } & \multicolumn{2}{|c|}{ Master } & \multicolumn{2}{|c|}{ Graduate \& Phd } & \multicolumn{2}{|c|}{ Sum } \\
\hline & $\mathrm{S}$ & $\%$ & $\mathrm{~S}$ & $\%$ & $\mathrm{~S}$ & $\%$ & $\mathrm{~S}$ & $\%$ & $\mathrm{~S}$ & $\%$ & $\mathrm{~S}$ & $\%$ \\
\hline Answers & 0 & 0 & 0 & 0 & 8 & 7.5 & 82 & 78.1 & 15 & 14.3 & 105 & 100 \\
\hline Year of & \multicolumn{2}{|c|}{ Under 5 years } & \multicolumn{2}{|c|}{$5-10$} & \multicolumn{2}{|c|}{$11-15$} & \multicolumn{2}{|c|}{$16-20$} & \multicolumn{2}{|c|}{ More than 20} & \multicolumn{2}{|c|}{ Sum } \\
\hline employment & $\mathrm{S}$ & $\%$ & $\mathrm{~S}$ & $\%$ & $\mathrm{~S}$ & $\%$ & $\mathrm{~S}$ & $\%$ & $\mathrm{~S}$ & $\%$ & $\mathrm{~S}$ & $\%$ \\
\hline Answers & 8 & 7.6 & 41 & 39 & 32 & 30.5 & 15 & 14.3 & 9 & 8.6 & 105 & 100 \\
\hline \multirow{2}{*}{ Age } & \multicolumn{2}{|c|}{ Under 25} & \multicolumn{2}{|c|}{$25-35$} & \multicolumn{2}{|c|}{$36-45$} & \multicolumn{2}{|c|}{$46-55$} & \multicolumn{2}{|c|}{ More than 55} & \multicolumn{2}{|c|}{ Sum } \\
\hline & S & $\%$ & S & $\%$ & S & $\%$ & $\mathrm{~S}$ & $\%$ & $\mathrm{~S}$ & $\%$ & S & $\%$ \\
\hline Answers & 0 & 0 & 42 & 40 & 35 & 33.3 & 24 & 22.9 & 4 & 3.8 & 105 & 100 \\
\hline
\end{tabular}

Table 5 demonstrates details of our survey on six components of trust, commitment, communication, conflict in management, basics of relational marketing and Islamic values.

Table 5

Descriptive statistics of research variables

\begin{tabular}{ccccccc}
\hline & Trust & Commitment & Communication & $\begin{array}{c}\text { Conflict } \\
\text { Management }\end{array}$ & $\begin{array}{c}\text { Basics of } \\
\text { Relational } \\
\text { Marketing }\end{array}$ & $\begin{array}{c}\text { Islamic } \\
\text { values }\end{array}$ \\
\hline Number & 105 & 105 & 105 & 105 & 105 & 105 \\
\hline No Answer & 0 & 0 & 0 & 0 & 0 & 0 \\
Average & 35.54 & 37.63 & 30.11 & 34.60 & 137.89 & 36.19 \\
Median & 37 & 38 & 31 & 36 & 140 & 35 \\
Mod & 45 & 43 & 34 & 34 & 156 & 35 \\
\hline Standard .D & 6.743 & 7.411 & 7.101 & 8.135 & 26.306 & 7.696 \\
\hline Variant & 45.462 & 54.928 & 50.429 & 66.185 & 692.006 & 59.233 \\
\hline Ranking & 25 & 31 & 29 & 36 & 110 & 34 \\
Min & 20 & 21 & 11 & 12 & 69 & 18 \\
\hline Max & 45 & 52 & 40 & 48 & 179 & 52 \\
\hline
\end{tabular}

Based on the information of Table 5, the average of the sixth item, Islamic values, is 36.19 also average of basics of relational marketing, trust, commitment and conflict management are 137.89, 35.54, 11.63, 30.37, and 34.60, respectively. Table 6 shows details of Pearson's test (Norusis, 2004) to examine the correlation on basics of relational marketing and its dimensions. According to calculated information from Table 6, Pearson's test meaningfully level is 0.001 and $\mathrm{P}=0.000$ for all of hypothesis at one scope meaningfully level. This is lower than minimum level of meaningfully i.e. 0.05. Calculated values for hypothesis numbers 1 to $1-4$ are $0.650,0.540,0.570,0.532$ and 0.670 , respectively. Therefore, these are higher than 0.174 critical value of Pearson's at confidential level of 0.95 and freedom grade of 104. 
Table 6

Pearson's test for the determining of Islamic values correlation on basics of relational marketing and its dimensions

\begin{tabular}{cccccc}
\hline Hypothesis & Variable & $\mathrm{N}$ & Type of test & Sig(2-tailed) & Islamic values \\
\hline 1 & Basics of Relational & 105 & Pearson's Correlation & 0.000 & 0.650 \\
& Marketing & 105 & Pearson's Correlation & 0.000 & 0.540 \\
$1-1$ & Trust & 105 & Pearson's Correlation & 0.000 & 0.570 \\
$1-2$ & Commitment & 105 & Pearson's Correlation & 0.000 & 0.532 \\
$1-3$ & Communication & 105 & Pearson's Correlation & 0.000 & 0.670 \\
\hline
\end{tabular}

Therefore, there is a meaningful relation between Islamic values and basics of relational marketing and its four dimensions, which are trust, commitment, communications and conflict management in West Azarbaijan alimentary industries. In addition, for evaluation of effectiveness of independent variable on dependent variable of all hypothesis two variable regressions is used and the results are summarized in Table 7.

Table 7

Variant analyze of regression model of Islamic values on basics of relational marketing related hypothesis

\begin{tabular}{|c|c|c|c|c|c|c|c|}
\hline \multirow{6}{*}{$\begin{array}{l}\text { Basics of } \\
\text { relational } \\
\text { marketing }\end{array}$} & \multicolumn{2}{|c|}{$\mathrm{R}$} & $\mathrm{R}^{\wedge} 2$ & \multicolumn{2}{|c|}{ Modified R^2 } & \multicolumn{2}{|c|}{ Standard Error } \\
\hline & \multicolumn{2}{|c|}{0.650} & 0.422 & \multicolumn{2}{|c|}{0.141} & \multicolumn{2}{|c|}{20.09074} \\
\hline & $\begin{array}{l}\text { Source of } \\
\text { changes }\end{array}$ & $\begin{array}{l}\text { Degree of } \\
\text { freedom }\end{array}$ & $\begin{array}{l}\text { Sum of } \\
\text { Squares }\end{array}$ & $\begin{array}{l}\text { Mean } \\
\text { Squares }\end{array}$ & $\mathrm{F}$ & $\begin{array}{c}\text { Confidence } \\
\text { level }\end{array}$ & $\begin{array}{c}\text { Meaningfully } \\
\text { level }\end{array}$ \\
\hline & Regression & 1 & 30393.915 & 30393.92 & \multirow{3}{*}{75.3} & 0.95 & 0.000 \\
\hline & Remain & 103 & 41574.713 & 96.080 & & \multirow{2}{*}{\multicolumn{2}{|c|}{ Null hypothesis is rejected }} \\
\hline & Total & 104 & 71968.629 & - & & & \\
\hline \multirow{6}{*}{$\begin{array}{l}\text { Trust dimension } \\
\text { of Basics of } \\
\text { relational } \\
\text { marketing }\end{array}$} & \multicolumn{2}{|c|}{$\mathrm{R}$} & $\mathrm{R}^{\wedge} 2$ & \multicolumn{2}{|c|}{ Modified R^2 } & \multicolumn{2}{|c|}{ Standard Error } \\
\hline & \multicolumn{2}{|c|}{0.540} & 0.292 & \multicolumn{2}{|c|}{0.285} & \multicolumn{2}{|c|}{5.70257} \\
\hline & $\begin{array}{l}\text { Source of } \\
\text { changes }\end{array}$ & $\begin{array}{l}\text { Degree of } \\
\text { freedom }\end{array}$ & $\begin{array}{l}\text { Sum of } \\
\text { Squares }\end{array}$ & $\begin{array}{l}\text { Mean } \\
\text { Squares }\end{array}$ & $\mathrm{F}$ & $\begin{array}{c}\text { Confidence } \\
\text { level }\end{array}$ & $\begin{array}{c}\text { Meaningfully } \\
\text { level }\end{array}$ \\
\hline & Regression & 1 & 1378.566 & 1378.66 & \multirow{3}{*}{42.4} & 0.95 & 0.000 \\
\hline & Remain & 103 & 3349.491 & 32.519 & & \multirow{2}{*}{\multicolumn{2}{|c|}{ Null hypothesis is rejected }} \\
\hline & Total & 104 & 4728.057 & - & & & \\
\hline \multirow{6}{*}{$\begin{array}{l}\text { Commitment } \\
\text { dimension of } \\
\text { Basics of } \\
\text { relational } \\
\text { marketing }\end{array}$} & \multicolumn{2}{|c|}{$\mathrm{R}$} & $\mathrm{R} \wedge 2$ & \multicolumn{2}{|c|}{ Modified R^2 } & \multicolumn{2}{|c|}{ Standard Error } \\
\hline & \multicolumn{2}{|c|}{0.570} & 0.325 & \multicolumn{2}{|c|}{0.319} & \multicolumn{2}{|c|}{6.11714} \\
\hline & $\begin{array}{l}\text { Source of } \\
\text { changes }\end{array}$ & $\begin{array}{l}\text { Degree of } \\
\text { freedom }\end{array}$ & $\begin{array}{l}\text { Sum of } \\
\text { Squares }\end{array}$ & $\begin{array}{l}\text { Mean } \\
\text { Squares }\end{array}$ & $\mathrm{F}$ & $\begin{array}{c}\text { Confidence } \\
\text { level }\end{array}$ & $\begin{array}{c}\text { Meaningfully } \\
\text { level }\end{array}$ \\
\hline & Regression & 1 & 1858.317 & 1858.32 & \multirow{3}{*}{49.7} & 0.95 & 0.000 \\
\hline & Remain & 103 & 3854.197 & 37.419 & & \multirow{2}{*}{\multicolumn{2}{|c|}{ Null hypothesis is rejected }} \\
\hline & Total & 104 & 5712.514 & - & & & \\
\hline \multirow{6}{*}{$\begin{array}{l}\text { Communications } \\
\text { dimension of } \\
\text { Basics of } \\
\text { relational } \\
\text { marketing }\end{array}$} & \multicolumn{2}{|c|}{$\mathrm{R}$} & $\mathrm{R} \wedge 2$ & \multicolumn{2}{|c|}{ Modified R^2 } & Star & Error \\
\hline & & & 0.283 & & & & 386 \\
\hline & $\begin{array}{l}\text { Source of } \\
\text { changes }\end{array}$ & $\begin{array}{l}\text { Degree of } \\
\text { freedom }\end{array}$ & $\begin{array}{l}\text { Sum of } \\
\text { Squares }\end{array}$ & $\begin{array}{l}\text { Mean } \\
\text { Squares }\end{array}$ & $\mathrm{F}$ & $\begin{array}{c}\text { Confidence } \\
\text { level }\end{array}$ & $\begin{array}{c}\text { Meaningfully } \\
\text { level }\end{array}$ \\
\hline & Regression & 1 & 1482.220 & 1482.2 & & 0.95 & 0.000 \\
\hline & Remain & 103 & 3762.409 & 36.528 & 40.6 & & \\
\hline & Total & 104 & 5244.629 & - & & Ivull & rejected \\
\hline & & & $\mathrm{R} \wedge 2$ & Modifi & $\wedge \wedge 2$ & Star & Error \\
\hline Conflict & & & 0.449 & & & & 731 \\
\hline dimension of & $\begin{array}{l}\text { Source of } \\
\text { changes }\end{array}$ & $\begin{array}{l}\text { Degree of } \\
\text { freedom }\end{array}$ & $\begin{array}{l}\text { Sum of } \\
\text { Squares }\end{array}$ & $\begin{array}{l}\text { Mean } \\
\text { Squares }\end{array}$ & F & $\begin{array}{c}\text { Confidence } \\
\text { level }\end{array}$ & $\begin{array}{c}\text { Meaningfully } \\
\text { level }\end{array}$ \\
\hline $\begin{array}{l}\text { Basics of } \\
\text { relational }\end{array}$ & Regression & 1 & 3091.543 & 3091.54 & & 0.95 & 0.000 \\
\hline marketing & Remain & 103 & 3791.657 & 36.812 & 84 & Null hyn & is reiected \\
\hline & Total & 104 & 6883.200 & - & & Null hyp & is is rejected \\
\hline
\end{tabular}


Based on captured information from Table 7, meaningfully level of regression test is $\mathrm{P}=0.000$. It can be claimed that mentioned test in meaningful at 95\% confidence level. Therefore, we can reject the null hypothesis in favor of H1. Based on the results, we can concludes that 42 percent of basics of relational marketing changes are affected by Islamic values changes and respectively 29,32,28,44 \% of Islamic values are affected by changes through trust, commitment, relationships and conflict management which are basics of relational marketing. Table 8 shows details of our regression analysis between different independent and dependent variables.

\section{Table 8}

Coefficients of Islamic values hypothesis on basics of relational marketing and its dimensions

\begin{tabular}{|c|c|c|c|c|c|c|}
\hline \multirow{3}{*}{$\begin{array}{l}\text { Islamic values and } \\
\text { effects on basics of } \\
\text { relational marketing }\end{array}$} & Variable Name & slope & t-student & P-value & $\begin{array}{c}\text { Null } \\
\text { Hypothesis }\end{array}$ & $\begin{array}{l}\text { Mathematic } \\
\text { formula }\end{array}$ \\
\hline & Width from origin & 57.498 & 6.072 & 0.000 & Reject & \multirow{2}{*}{$\begin{array}{c}\mathrm{Y}= \\
57.498+2.221 \mathrm{X}\end{array}$} \\
\hline & Islamic values & 2.221 & 8.678 & 0.000 & Reject & \\
\hline \multirow{2}{*}{$\begin{array}{l}\text { Islamic values and } \\
\text { effects on trust } \\
\text { dimension of basics } \\
\text { of relational } \\
\text { marketing }\end{array}$} & Width from origin & 18.423 & 6.854 & 0.000 & Reject & \multirow[b]{2}{*}{$\begin{array}{c}\mathrm{Y}= \\
18.423+0.473 \mathrm{X}\end{array}$} \\
\hline & Islamic values & 0.473 & 8.511 & 0.000 & Reject & \\
\hline \multirow{2}{*}{$\begin{array}{l}\text { Islamic values and } \\
\text { effects on } \\
\text { commitment } \\
\text { dimension of basics } \\
\text { of relational } \\
\text { marketing }\end{array}$} & Width from origin & 17.751 & 6.157 & 0.000 & Reject & \multirow[b]{2}{*}{$\begin{array}{c}Y= \\
17.751+0.549 \mathrm{X}\end{array}$} \\
\hline & Islamic values & 0.549 & 7.047 & 0.000 & Reject & \\
\hline \multirow{2}{*}{$\begin{array}{l}\text { Islamic values and } \\
\text { effects on } \\
\text { communication } \\
\text { dimension of basics } \\
\text { of relational } \\
\text { marketing } \\
\end{array}$} & Width from origin & 12.362 & 4.340 & 0.000 & Reject & \multirow[b]{2}{*}{$\begin{array}{c}\mathrm{Y}= \\
12.362+0.491 \mathrm{X}\end{array}$} \\
\hline & Islamic values & 0.491 & 6.370 & 0.000 & Reject & \\
\hline \multirow{3}{*}{$\begin{array}{l}\text { Islamic values and } \\
\text { effects on conflict } \\
\text { management } \\
\text { dimension of basics } \\
\text { of relational } \\
\text { marketing }\end{array}$} & Width from origin & 8.962 & 3.134 & 0.000 & Reject & \multirow{3}{*}{$\mathrm{Y}=8.962+0.708 \mathrm{X}$} \\
\hline & Islamic values & 0.708 & 9.164 & 0.000 & Reject & \\
\hline & $\begin{array}{l}\text { Life overall } \\
\text { atmosphere }\end{array}$ & 1.109 & 0294 & 0.000 & Reject & \\
\hline
\end{tabular}

So it can be concluded that a one percents increase in independent variable, Islamic values, will generate an increase of 2.221 times on West Azarbaijan alimentary industries' value. In addition, one unit increase of Islamic values as independent variable will result to an increase of 0.473 times on trust dimension value, 0.549 times increase on commitment value, 0.491 on communications and 0.708 on conflict management value.

\subsection{Suggestions}

In order to reinforcement of Islamic values concern with relational marketing basics on West Azarbaijan alimentary industries we may use different suggestions. There is no doubt that establishing effective relationship with costumers based on Islamic values could be achieved by encouraging employees on reading books or participating in appropriate conferences. The hiring must be accomplished based on Islamic rules as well as people's educations and company's requirement. The firm must maintain strong commitment to meet customers' needs. The promotion plans must be based on Islamic rules and customers must be satisfied on what they buy from the company. The firms must prevent of using misleading advertisement and any abusing system. Firms must take care of the feedbacks customers send back to firms in an attempt to improve the quality and reliability of 
the products. Marketing development needs to be on Islamic rules, which includes ongoing relationships with customers, detecting customers' need and informing them about the new products and maintaining on time services. Pricing is another issue associated with the product and it must be according to product characteristics. Firms do not have to charge for low quality products, they do not have to mislead customers to purchase products; they do not have discriminate customers. Quality is a priority according to Islamic rules and firms must comply with highest levels of quality. Customer relationship management must also be based on Islamic rules, employees need to have outstanding relationship with their customers according to Islamic rules and regulation and customers must be treated with respect.

\section{Conclusions}

In this paper, we have presented an empirical study to investigate the relationship between Islamic values and marketing affairs in the field of alimentary industries of West Azarbaijan province, Iran. The proposed study designed a questionnaire and distributed among 105 managers out of 145 ones and analyzed the data using different statistical methods. The preliminary results indicated that Islamic values significantly influence trust, commitment and communication among members of business units and it could help resolve conflict management, substantially. The paper provided some guidelines for better managing firms in the region by attaching on Islamic values for marketing products and preventing unethical methods in mislead customers.

\section{Acknowledgment}

The authors are most grateful for generous contribution of the anonymous referees on earlier version of this paper.

\section{References}

Ahmad, K. (2000). Islamic finance and banking: the challenge and Prospects. Review of Islamic Economics, 9, 57-82.

Ahmad, N., \& Haron, S. (2002). Perceptions of Malaysian corporate customers towards Islamic banking products and services. International Journal of Islamic Financial Services, 3(4), 13-29.

Al-Khater, K., \& Naser, K. (2003). Users' perceptions of corporate social responsibility and accountability: evidence from an emerging economy. Managerial Auditing Journal, 18(6/7), 53848.

Arslan, M. (2001). The work ethic values protestant British, catholic largish and Muslim. Turkish Managers Journal of Business Ethics, 13, 321-339.

Cronbach, L. J. (1951). Coefficient alpha and the internal structure of tests. Psychometrika, 16(3), 297-334.

Dusuki, A.W. \& Abdullah, N. I. (2007) Maqasid al-Shari`ah, Maslahah and Corporate Social Responsibility. The American Journal of Islamic Social Science. 24(1), 25-45.

Dusuki, A.W. \& Abdullah, N. I. (2007). Way do Malaysian customers patronize Islamic banks? International Journal of Bank Marketing, 25(3), 142-160.

Hunt, S. D., \& Vitell, S. (1986). A general theory of marketing ethics. Journal of Macromarketing, 6(1), 5-16.

Lund, D.B. (2000). An empirical examination of marketing professionals' ethical behavior in differing situations. Journal of Business Ethics, 24, 331-342.

Likert, R. (1932). A Technique for the Measurement of Attitudes. Archives of Psychology, 140, 155.

Morgan, R. M., \& Hunt, S.D. (1994). The commitment - trust theory of relationship marketing. Journal of Marketing, 58(3), 20-38.

Ndubisi, N. O. (2007). Relationship marketing and customer loyalty. Marketing Intelligence Planning, 25(1), 98-106. 
Norusis, M.J. (2004). SPSS 12.0: Guide to Data Analysis, Prentice Hall. Englewood Cliffs, NJ.

Othman, A., \& Owen, L. (2001). Adopting and measuring customer service quality (SQ) in Islamic banks: a case study in Kuwait finance house. International Journal of Islamic Financial Services, 3(1), $1-26$.

Porter, M.E., \& Kramer, M.R. (2002). The competitive advantage of corporate philanthropy. Harvard Business Review, 80, 56-65.

Wilson, R. (1997). Islamic finance and ethical investment. International Journal of Social Economics, 24(11), 1325-1342. 